\title{
Links between surface productivity and deep ocean particle flux at the Porcupine Abyssal Plain sustained observatory
}

\author{
H. Frigstad ${ }^{1, \text { a }}$, S. A. Henson ${ }^{2}$, S. E. Hartman ${ }^{2}$, A. M. Omar ${ }^{1,3}$, E. Jeansson ${ }^{1}$, H. Cole ${ }^{4}$, C. Pebody ${ }^{2}$, and R. S. Lampitt ${ }^{2}$ \\ ${ }^{1}$ Uni Research Climate, Allégaten 55, 5007 Bergen, Norway \\ ${ }^{2}$ National Oceanography Centre, Waterfront Campus, European Way, Southampton, SO14 3ZH, UK \\ ${ }^{3}$ Geophysical Institute, University of Bergen, Allégaten 79, 5007 Bergen, Norway \\ ${ }^{4}$ Ocean and Earth Sciences, University of Southampton Waterfront Campus, European Way, Southampton, SO14 3ZH, UK \\ a now at: Department of Climate, Norwegian Environment Agency, Grensesvingen 7, 0661 Oslo, Norway
}

Correspondence to: H. Frigstad (helene.frigstad@miljodir.no)

Received: 9 March 2015 - Published in Biogeosciences Discuss.: 1 April 2015

Revised: 31 August 2015 - Accepted: 13 September 2015 - Published: 15 October 2015

\begin{abstract}
In this study we present hydrography, biogeochemistry and sediment trap observations between 2003 and 2012 at Porcupine Abyssal Plain (PAP) sustained observatory in the Northeast Atlantic. The time series is valuable as it allows for investigation of the link between surface productivity and deep ocean carbon flux. The region is a perennial sink for $\mathrm{CO}_{2}$, with an average uptake of around $1.5 \mathrm{mmol} \mathrm{m}^{-2}$ day $^{-1}$. The average monthly drawdowns of inorganic carbon and nitrogen were used to quantify the net community production (NCP) and new production. Seasonal NCP and new production were found to be $4.57 \pm 0.85 \mathrm{~mol} \mathrm{C} \mathrm{m}^{-2}$ and $0.37 \pm 0.14 \mathrm{~mol} \mathrm{~N} \mathrm{~m}^{-2}$, respectively. The $\mathrm{C}: \mathrm{N}$ ratio was high (12) compared to the Redfield ratio (6.6), and the production calculated from carbon was higher than production calculated from nitrogen, which is indicative of carbon overconsumption. The export ratio and transfer efficiency were 16 and $4 \%$, respectively, and the site thereby showed high flux attenuation. Particle tracking was used to examine the source region of material in the sediment trap, and there was large variation in source regions, both between and within years. There were higher correlations between surface productivity and export flux when using the particle-tracking approach, than by comparing with the mean productivity in a $100 \mathrm{~km}$ box around the PAP site. However, the differences in correlation coefficients were not significant, and a longer time series is needed to draw conclusions on applying particle tracking in sediment trap analyses.
\end{abstract}

\section{Introduction}

The Porcupine Abyssal Plain (PAP) sustained observatory is situated in the Northeast Atlantic Ocean $\left(49^{\circ} \mathrm{N}, 16.5^{\circ} \mathrm{W}\right)$ in a water depth of $4800 \mathrm{~m}$. It is near the boundary between the sub-polar and sub-tropical gyres of the North Atlantic (Henson et al., 2009). A time series of particle flux measurements at $3000 \mathrm{~m}$ depth are available back to the early 1990's (Lampitt et al., 2010), and since 2003 there has also been a multidisciplinary mooring with instruments at approximately $30 \mathrm{~m}$ depth recording hydrography, nitrate $\left(\mathrm{NO}_{3}^{-}\right)$, partial pressure of $\mathrm{CO}_{2}\left(p \mathrm{CO}_{2}\right)$ and Chlorophyll $a(\mathrm{Chl} a)$ (Hartman et al., 2012). The simultaneous observations of surface and deep ocean biogeochemistry make this time series ideal to study linkages between surface ocean productivity and deep ocean particle flux.

The pathway by which a small fraction $(<1 \%$; Martin et al., 1987) of the carbon fixed by photosynthesis in the sunlit upper ocean is exported to great depths, thereby constituting a sink for atmospheric $\mathrm{CO}_{2}$, is referred to as the biological carbon pump. Carbon sinking to the deep ocean is sequestered on long timescales (100s to 1000s of years), and therefore quantifying the biological carbon pump is key in understanding the global carbon cycle (Falkowski et al., 1998). These factors are currently not fully understood, so it is therefore difficult to predict how they will respond to climate change (e.g. Passow and Carlson, 2012).

Primary production in the surface ocean can be measured by several techniques (broadly separated into vitro incu- 
bations or changes in bulk properties; Platt et al., 1989), however, from the perspective of the oceanic carbon cycle the most important rate is the net community production (NCP). NCP is the net primary production (NPP) minus heterotrophic respiration, and represents the sum of the particulate and dissolved organic carbon available for export or utilization by higher trophic levels. NCP is traditionally measured by bottle $\mathrm{O}_{2}$ incubations (Gaarder and Gran, 1927), but has also been estimated from oxygen or carbon budgets, ${ }^{234}$ Thorium, sediment traps and $\mathrm{O}_{2} / \mathrm{Ar}$ ratios. It can be challenging to compare between techniques and there is a poor understanding of NCP rates in many regions of the ocean (Quay et al., 2010). In many studies, the steady-state NCP is equated with the export flux at the base of the euphotic zone (Platt et al., 1989; Lee, 2001; Long et al., 2011; Nevison et al., 2012), based on the rationale that NCP is the organic material available for export out of the mixed layer. However, it is not directly comparable to the most common definition of export flux (i.e. the downward flux of POC at a nominal depth) as NCP represents a bulk measurement integrated over the mixed layer and long timescales (and also includes the contribution of DOC to export). The export ratio (i.e. Dugdale and Goering, 1967) is used to quantify the proportion of the organic material produced that is exported below the euphotic zone, and is often calculated as the flux of POC at $100 \mathrm{~m}$ divided by the NPP (Henson et al., 2012b). Global estimates of the export ratio range from $10 \%$ (Henson et al., 2011) to $40 \%$ (Eppley and Peterson, 1979), and is well correlated with temperature, and thereby also latitude (Laws et al., 2000).

The new production, Dugdale and Goering (1967), is the production supported by the input of new nitrogen into the euphotic zone through upwelling and horizontal mixing, but also by processes such as atmospheric deposition and nitrogen fixation (Sarmiento and Gruber, 2006; Gruber, 2008). On an annual basis, assuming the system is in a steady state, export production is considered equivalent to new production (Eppley and Peterson, 1979).

From a climate change perspective, the long-term (> 100 years) removal of carbon from the atmosphere is important to quantify, which is often defined as the flux of carbon below $1000 \mathrm{~m}$ (Lampitt et al., 2008a), known as the sequestration flux. The sequestration flux is smaller than the export flux out of the euphotic zone or mixed layer, and is $\sim 6-25 \%$ of the new production based on sediment trap data (Berelson, 2001; Francois et al., 2002). This large reduction in carbon flux with increasing depth is caused by intensive remineralization of organic material as it sinks through the mesopelagic zone, which is often referred to as flux attenuation (Martin et al., 1987; Steinberg et al., 2008). The ratio of deep POC flux to export flux (POC flux at $2000 \mathrm{~m} / \mathrm{POC}$ flux at $100 \mathrm{~m}$ ) is known as the transfer efficiency and has often been used to describe the efficiency of the biological pump (Francois et al., 2002; De La Rocha and Passow, 2012; Henson et al., 2012b). It should be noted that the POC-based metric of calculating export flux and transfer efficiency does not include the contribution from DOC.

In this study we present a time series of surface ocean measurements and particle trap data from the PAP observatory station from 2003 to 2012. Our aim is twofold; firstly, we will quantify NCP and new production from the average monthly drawdown of dissolved inorganic carbon (DIC) and $\mathrm{NO}_{3}^{-}$, respectively. This allows us to compare these two estimates of surface productivity, and derive export ratios by comparison with satellite NPP estimates and published values of shallow POC flux at the PAP observatory. Secondly, we will investigate the link between the production at the surface and particle flux at $3000 \mathrm{~m}$ depth, both by investigating the transfer efficiency and by examining the source location of exported material using particle-tracking techniques.

\section{Data and methods}

\subsection{PAP surface mooring}

Hydrographical and biogeochemical parameters were measured using data from instruments at a nominal $30 \mathrm{~m}$ depth on a mooring at the PAP observatory $\left(49^{\circ} \mathrm{N}, 16.5^{\circ} \mathrm{W}\right)$. The surface mooring was first deployed in July 2003, and more information about the time series can be found in Hartman et al. (2012). Due to problems with damage to the mooring and/or failure of sensors, there is no or little data between 2005 and 2010, however, after May 2010 there is good temporal coverage for all biogeochemical parameters. The data from 2003-2005 have previously been published in Körtzinger et al. (2008) and Hartman et al. (2010). The sensors used after 2005 are described in Table 1 in Hartman et al. (2012). NAS nutrient analysers (Envirotech LLC) were used in the period from 2002 until 2012, which measures $\mathrm{NO}_{3}^{-}$plus $\mathrm{NO}_{2}^{-}$(hereafter referred to as $\mathrm{NO}_{3}^{-}$) with a precision of $\pm 0.05 \mu \mathrm{mol} \mathrm{L}^{-1}$. The NAS was used alongside an optical nitrate sensor from 2009 to 2012, after that time all $\mathrm{NO}_{3}^{-}$measurements were made with optical sensors (Satlantic ISUS), with a precision of $2 \mu \mathrm{mol} \mathrm{L}^{-1}$. For the remaining variables a Seabird MicroCAT was used for temperature and salinity, Wetlabs (FLNTUSB) for Chl $a$ and PRO-OCEANUS for $p \mathrm{CO}_{2}$. The $\mathrm{NO}_{3}^{-}$, Chl $a$ and $p \mathrm{CO}_{2}$ data have all been quality controlled and calibrated against CTD data on cruises to the PAP observatory at deployment and/or recovery of the mooring, while this has not always been achieved for temperature and salinity.

\subsection{Sediment trap}

The sediment trap mooring at the PAP observatory was deployed in the depth range 3000 to $3200 \mathrm{~m}$, which is around $1800 \mathrm{~m}$ above the seabed. The methodology is described in Lampitt et al. (2010). Briefly, a Parflux sediment trap was used with mouth area $0.5 \mathrm{~m}^{2}$, prefilled with hypersaline 
Table 1. Overview of ancillary data.

\begin{tabular}{|c|c|}
\hline Parameter & Source \\
\hline $\begin{array}{l}\text { ARGO Temperature } \\
\text { and salinity }\end{array}$ & $\begin{array}{l}\text { Temperature and salinity fields: } 1^{\circ} \text { by } \\
1^{\circ} \text {, monthly temporal resolution. Depth } \\
\text { in profiles had resolution of } 5 \mathrm{~m} \text { be- } \\
\text { tween } 10 \text { and } 100 \mathrm{~m} \text { and } 10 \mathrm{~m} \text { between } \\
100 \text { and } 800 \mathrm{~m} \text {. Available through Cori- } \\
\text { olis project; http://www.coriolis.eu.org/ }\end{array}$ \\
\hline Atmospheric $\mathrm{CO}_{2}$ & $\begin{array}{l}\text { Mace Head land station in Ireland } \\
\left(53.33^{\circ} \mathrm{N}, 9.90^{\circ} \mathrm{W}\right) \text { from the Coop- } \\
\text { erative Atmospheric Data Integration } \\
\text { Projects (GLOBALVIEW-CO2, 2012); } \\
\text { http://www.esrl.noaa.gov/gmd/ccgg/ } \\
\text { globalview/co2/co2_download.html }\end{array}$ \\
\hline $\begin{array}{l}\text { Sea Level Pressure } \\
\text { (SLP) }\end{array}$ & $\begin{array}{l}\text { FNMOC } 1^{\circ} \text { by } 1^{\circ}, 6 \text {-hourly; } \\
\text { http://coastwatch.pfeg.noaa.gov/ } \\
\text { erddap/griddap/erdlasFnPres6.html }\end{array}$ \\
\hline Wind speed & $\begin{array}{l}\text { FNMOC } 1^{\circ} \text { by } 1^{\circ} \text {, 6-hourly at } 10 \mathrm{~m} \\
\text { height; http://coastwatch.pfeg.noaa. } \\
\text { gov/erddap/griddap/erdlasFnWPr.html }\end{array}$ \\
\hline $\begin{array}{l}\text { Net primary production } \\
\text { (NPP) }\end{array}$ & $\begin{array}{l}\text { Vertically Generalised } \\
\text { Production Model; http://www.science. } \\
\text { oregonstate.edu/ocean.productivity/ } \\
\text { index.php }\end{array}$ \\
\hline
\end{tabular}

buffered formalin, following the JGOFS protocols. The collection period varied between 2 and 8 weeks depending on the time of year and anticipated flux. All fluxes are temporally and spatially integrated, and given in either $\mathrm{ml} \mathrm{m}^{-2} \mathrm{~d}^{-1}$ (volume flux) or $\mathrm{mg} \mathrm{m}^{-2} \mathrm{~d}^{-1}$ (dry weight and Particulate Organic Carbon (POC)).

\subsection{Ancillary data and calculated parameters}

To interpret and expand on the data from the PAP observatory, the following parameters were used from external data sources (see Table 1): temperature and salinity profiles from Argo floats, atmospheric $\mathrm{CO}_{2}$ concentration, sea level barometric pressure (SLP), wind speed at $10 \mathrm{~m}$ height and satellite-derived net primary production (NPP).

Temperature and salinity profiles were extracted from the global fields for the PAP observatory $\left(49^{\circ} \mathrm{N}, 16.5^{\circ} \mathrm{W}\right)$, made available by the Coriolis project (http://www.coriolis.eu.org). The gridded fields use temperature and salinity profiles collected by Argo floats, XBTs, CTD/XCTDs and moorings, and the irregularly sampled data are gridded onto a regularly spaced grid by the statistical objective analysis method (Gaillard et al., 2009). The North Atlantic is the region most frequently sampled by Argo floats and has good coverage in both time and space (Gaillard et al., 2009). Here we use monthly averaged temperature and salinity fields for 2002 2009 (delayed mode data), however, after 2010 only nearreal-time data were available, which has undergone less rigorous quality control than the delayed mode data. In the cal- culation of carbon parameters (below) the Argo float temperature and salinity at $30 \mathrm{~m}$ were used, because of data gaps in the temperature and salinity data from the PAP sensor (referred to as Argo temperature and salinity in text and Figs. 1 and 2) and the lack of consistent calibration with CTD data. Density profiles were calculated using the recently updated standard for seawater properties (TEOS-10; www.teos-10.org). The mixed layer depth (MLD) was calculated from density profiles using the same global gridded fields used for the temperature and salinity data at $30 \mathrm{~m}$. The depth of the mixed layer was defined by a density difference of $0.03 \mathrm{~kg} \mathrm{~m}^{-3}$ from the density at a reference depth (in this case $10 \mathrm{~m}$ to avoid diurnal changes in temperature and salinity at the surface). We followed the algorithm developed by Holte and Talley (2009), which incorporates linear interpolation to estimate the exact depth at which the density difference is crossed.

The atmospheric $\mathrm{CO}_{2}$ concentration measurements were obtained from the observatory closest to the PAP observatory, the Mace Head land station in Ireland $\left(53.33^{\circ} \mathrm{N}\right.$, $9.90^{\circ} \mathrm{W}$ ) from the Cooperative Atmospheric Data Integration Projects (GLOBALVIEW-CO2, 2012). There were no measurements available after 2010 , and so the annual averaged growth rate in atmospheric $\mathrm{CO}_{2}$ for marine sites from the NOAA ESRL data for $2011\left(1.69 \mu \mathrm{mol} \mathrm{mol}^{-1}\right)$ and $2012\left(2.59 \mu \mathrm{mol} \mathrm{mol}^{-1}\right)$ was added to the seasonal cycle in $\mathrm{CO}_{2}$ concentrations at the Mace Head station for 2010 (http: //www.esrl.noaa.gov/gmd/ccgg/trends/global.html). The atmospheric $p \mathrm{CO}_{2}$ was calculated using the Mace Head station $\mathrm{CO}_{2}$ measurements at barometric pressure (6-hourly Sea Level Pressure; Table 1) and equilibrium water vapour pressure (from Argo temperature and salinity at $30 \mathrm{~m}$; Table 1).

The air-sea $\mathrm{CO}_{2}$ flux (in mmol m${ }^{-2} \mathrm{~d}^{-1}$ ) was calculated from the air-sea $p \mathrm{CO}_{2}$ difference, Argo temperature and salinity $(30 \mathrm{~m})$ and wind speed at $10 \mathrm{~m}$ height, using the following equation:

$F_{\mathrm{CO}_{2}}=k \times K_{0} \times\left(p \mathrm{CO}_{2 \text { sea }}-p \mathrm{CO}_{2 \text { air }}\right)$,

where $k$ is the transfer coefficient based on the wind speeddependent formulation of Nightingale et al. (2000) scaled to the temperature-dependent Schmidt number according to Wanninkhof (1992), $K_{0}$ is the $\mathrm{CO}_{2}$ solubility at in situ temperature and salinity (Argo temperature and salinity at $30 \mathrm{~m}$ ) after Weiss (1974), while $p \mathrm{CO}_{2 \text { sea }}$ and $p \mathrm{CO}_{2}$ air are the $\mathrm{CO}_{2}$ partial pressures of seawater and air, respectively.

The alkalinity (Alk) was calculated from Argo temperature and salinity $(30 \mathrm{~m})$, following the relationship for the North Atlantic developed by Lee et al. (2006). The dissolved inorganic carbon (DIC) was calculated from Alk and measured $p \mathrm{CO}_{2}$ using the "seacarb" package (Lavigne and Gattuso, 2011), developed for R (R Development Core Team, 2012), using Argo temperature and salinity $(30 \mathrm{~m})$ and nutrient concentrations set to zero. The chosen constants were Lueker et al. (2000) for $K_{1}$ and $K_{2}$, Perez and Fraga (1987) for $K_{f}$ 

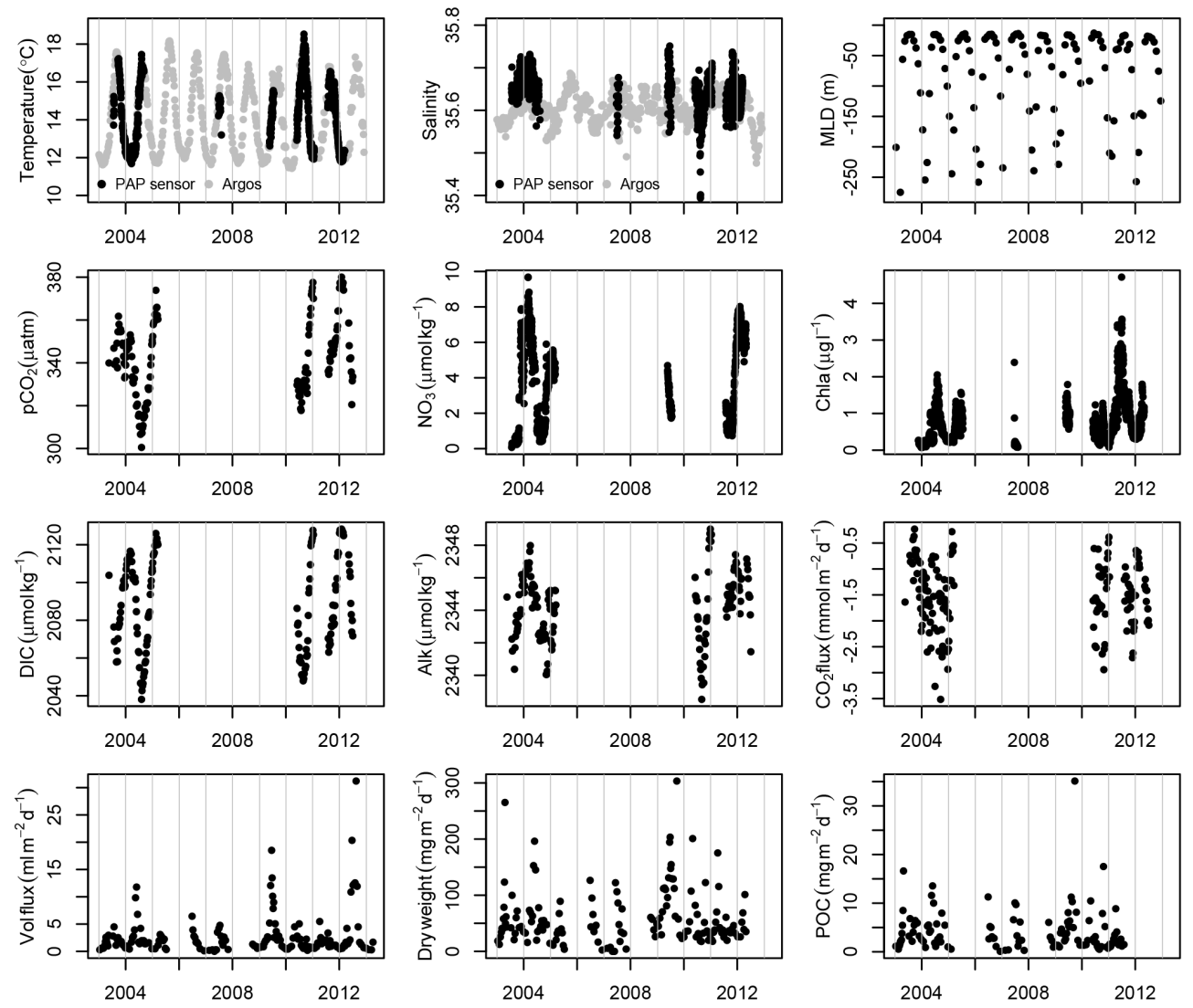

Figure 1. Time series of available data from PAP surface mooring and sediment trap with \pm 1 SD (vertical bars). Temperature and salinity calculated from the Argo float data (grey dots in first two panels) is also shown, along with derived mixed layer depth estimates. Negative $\mathrm{CO}_{2}$ flux values indicate flux from the atmosphere to the ocean.

and the Dickson (1990) constant for $K_{\mathrm{s}}$, as recommended by Dickson et al. (2007).

The seasonal drawdown of DIC and $\mathrm{NO}_{3}^{-}$were used to quantify the NCP and new production, respectively. The gaps in the PAP time series did not allow for examination of the seasonal drawdown on an annual basis (except for the year of 2004, as published by Körtzinger et al. (2008). However, for most months of the year data from at least two to four different years were available, and $\mathrm{NCP}_{\mathrm{MLD}}$ and $\mathrm{NO}_{3}$ MLD was estimated two to four times for each of these months. This allowed the quantification of the average seasonal NCP $\mathrm{MLD}_{\mathrm{M}}$ and $\mathrm{NO}_{3}$ MLD and variability (expressed as one standard deviation; SD) from the PAP time series. With the exception of March and April for NCP $\mathrm{MLD}_{\mathrm{ML}}$, when there was only data for 1 year (2004) and consequently SD could not be calculated (error bars missing in Fig. 3). The monthly changes in Eqs. (3) and (4) (below) were computed in a circular manner, i.e., the change in the 12th month is the difference between January minus December. For $\mathrm{NO}_{3}$ MLD there was only data for 1 year in December, and consequently the SD could not be calculated. For $\mathrm{NCP}_{\mathrm{MLD}}$ there was data from 2 different years in December and 3 years in January, however they coincided only for 2004. Therefore, the variability could not be determined for December for both $\mathrm{NCP}_{\mathrm{MLD}}$ and $\mathrm{NO}_{3} \mathrm{MLD}$ (error bar missing for December in Fig. 3).

A different source of uncertainty in NCP and new production estimates come from measurement uncertainty, which propagates into calculated values. However, for new production, the variability associated with measurement uncertainty is negligible compared to the natural variability. The measurement uncertainty for the $\mathrm{NO}_{3}^{-}$sensor given by the manufacturer (Satlantic ISUS V3 sensor) was $2 \mu$ molkg kg ${ }^{1}$. This gives a propagated probable error in the $\mathrm{NO}_{3}$ MLD estimates of $<0.05 \mathrm{~mol} \mathrm{~N} \mathrm{~m}^{-2}$ (calculated from the square root of the sum of squared errors), which is considered negligible compared to the uncertainty associated with monthly variation of $\pm 0.14 \mathrm{~mol} \mathrm{~N} \mathrm{~m}^{-2}$. Therefore we present the uncertainty related to monthly variation in $\mathrm{NO}_{3} \mathrm{MLD}$. Conversely, the total uncertainty associated with monthly variations in $\mathrm{NCP}_{\mathrm{MLD}}$ was $\pm 0.85 \mathrm{molC} \mathrm{m}^{-2}$, which is smaller than the total error associated with the calculation of DIC from estimated TA and measured $f \mathrm{CO}_{2}$ of $\pm 0.27 \mathrm{~mol} \mathrm{C} \mathrm{m}^{-2}$. The latter was determined by propagation using the method described in Dickson and Riley (1978), together with the errors in the estimated TA values ( $\pm 6.4 \mu$ molkg $^{-1}$; Lee et al., 2006) 

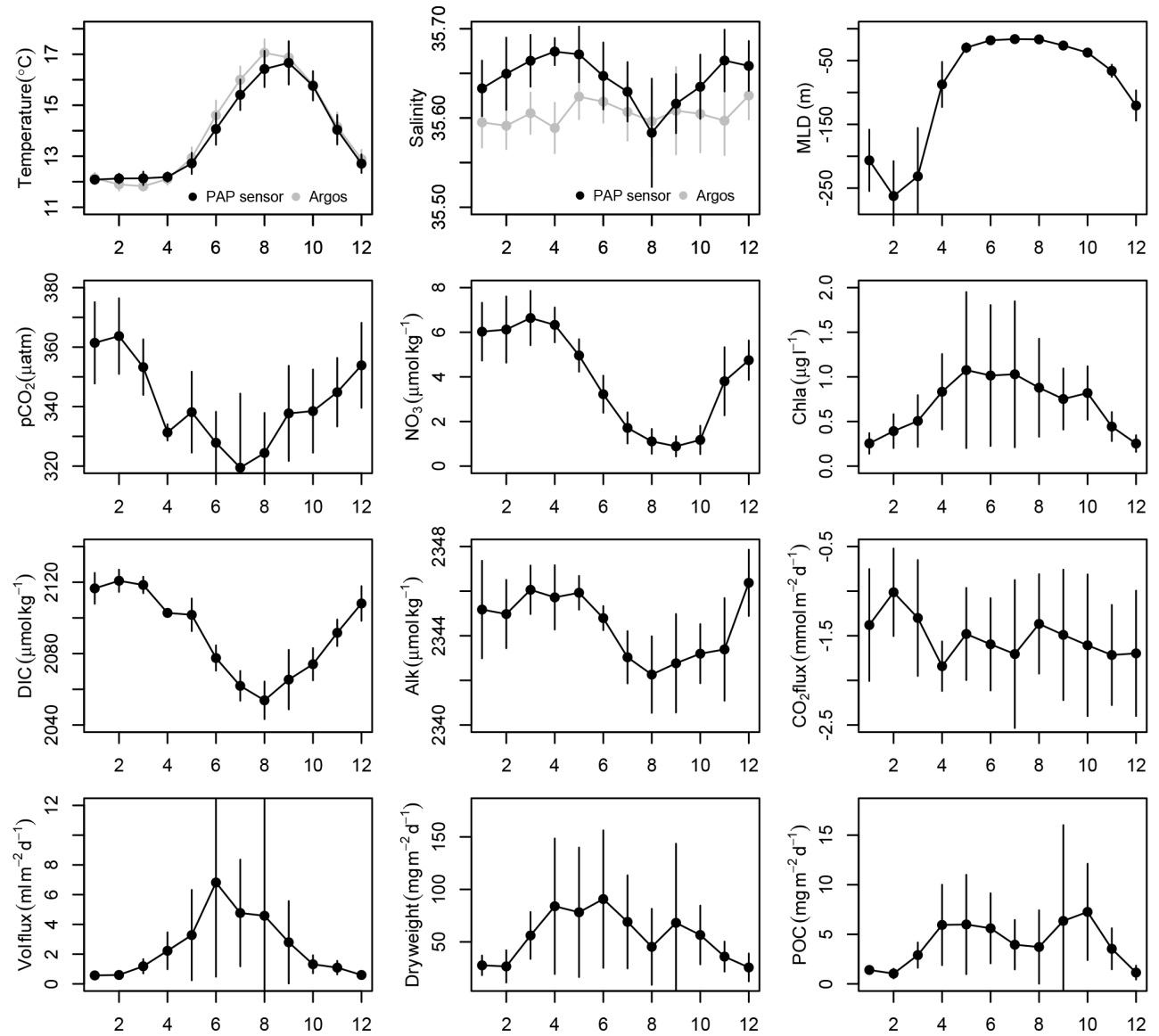

Figure 2. Monthly climatology (black dots) with $\pm 1 \mathrm{SD}$ (vertical bars) of available data from PAP surface mooring (30 m) and sediment trap. Temperature and salinity calculated from the Argo float data (grey dots in first two panels) is also shown, along with derived mixed layer depth estimates.

and measured $p \mathrm{CO}_{2}( \pm 2 \mu \mathrm{atm}$; Wanninkhof et al., 2013). We have therefore chosen to present the propagated probable error as a conservative estimate of the uncertainty in our NCP estimates.

The monthly changes in DIC concentrations $\left(\Delta \mathrm{DIC}_{\mathrm{obs}}\right)$ can be attributed to changes caused by air-sea gas exchange $\left(\Delta \mathrm{DIC}_{\mathrm{gas}}\right)$, physical mixing processes $\left(\Delta \mathrm{DIC}_{\mathrm{mix}}\right)$ and biological production $\left(\triangle \mathrm{DIC}_{\mathrm{BP}}\right)$. The monthly $\left(\triangle \mathrm{DIC}_{\mathrm{gas}}\right)$ (in $\mu \mathrm{mol} \mathrm{kg}{ }^{-1}$ ) can be estimated from the air-sea $\mathrm{CO}_{2}$ flux $\left(F_{\mathrm{CO}_{2}}\right)$ and MLD by the following formulation:

$\Delta \mathrm{DIC}_{\mathrm{gas}}=\frac{F_{\mathrm{CO}_{2}}}{\mathrm{MLD}} \times \frac{365}{12}$.

Physical mixing processes, such as vertical entrainment, diffusion and advection, will to some degree contribute to monthly DIC changes, however they are difficult to quantify without information on vertical and horizontal gradients. Following the approach by Körtzinger et al. (2008) we have performed a simplified calculation of seasonal NCP and new production for the summer period when the mixed layer is relatively stable and the biological drawdown in DIC (and $\mathrm{NO}_{3}^{-}$) is strong. Therefore, the contribution of $\Delta \mathrm{DIC}_{\mathrm{mix}}$ was assumed negligible, and $\triangle \mathrm{DIC}_{\mathrm{BP}}$ was assumed to be largely determined by NCP (excluding the effect of calcification). The monthly NCP integrated over the MLD (NCP $\mathrm{MLD}$ in $\mathrm{mol} \mathrm{C} \mathrm{m}^{-2}$ ) was calculated from the monthly changes in DIC corrected for the effects of air-sea gas exchange $\left(\Delta \mathrm{DIC}^{\mathrm{Gas} C o r r}=\Delta \mathrm{DIC}_{\mathrm{obs}}+\Delta \mathrm{DIC}_{\mathrm{gas}}\right):$

$$
\begin{aligned}
& \mathrm{NCP}_{\mathrm{MLD}}= \\
& \left(\Delta \mathrm{DIC}_{m+1}^{\mathrm{GasCorr}}-\Delta \mathrm{DIC}_{m}^{\mathrm{GasCorr}}\right) \times \frac{\left(\mathrm{MLD}_{m+1}+\mathrm{MLD}_{m}\right)}{2},
\end{aligned}
$$

where $\Delta \mathrm{DIC}_{m+1}^{\mathrm{GasCorr}}-\Delta \mathrm{DIC}_{m}^{\mathrm{GasCorr}}$ is the difference in $\Delta \mathrm{DIC}^{\mathrm{GasCorr}} \Delta \mathrm{DIC} \mathrm{C}^{\text {GasCorr }}$ between two consecutive months $(m$ and $m+1)$ and the last term gives the average MLD of the two months. Positive values of $\mathrm{NCP}_{\mathrm{MLD}}$ represent net autotrophy (i.e. the months where the biological drawdown of DIC exceeds the DIC released by heterotrophic processes), and the seasonal $\mathrm{NCP}_{\mathrm{MLD}}$ can then be calculated as the sum of months with a positive NCP.

The same rationale can be applied to the monthly changes in $\mathrm{NO}_{3}^{-}$concentrations $\left(\Delta \mathrm{NO}_{3}\right)$, naturally without having to 

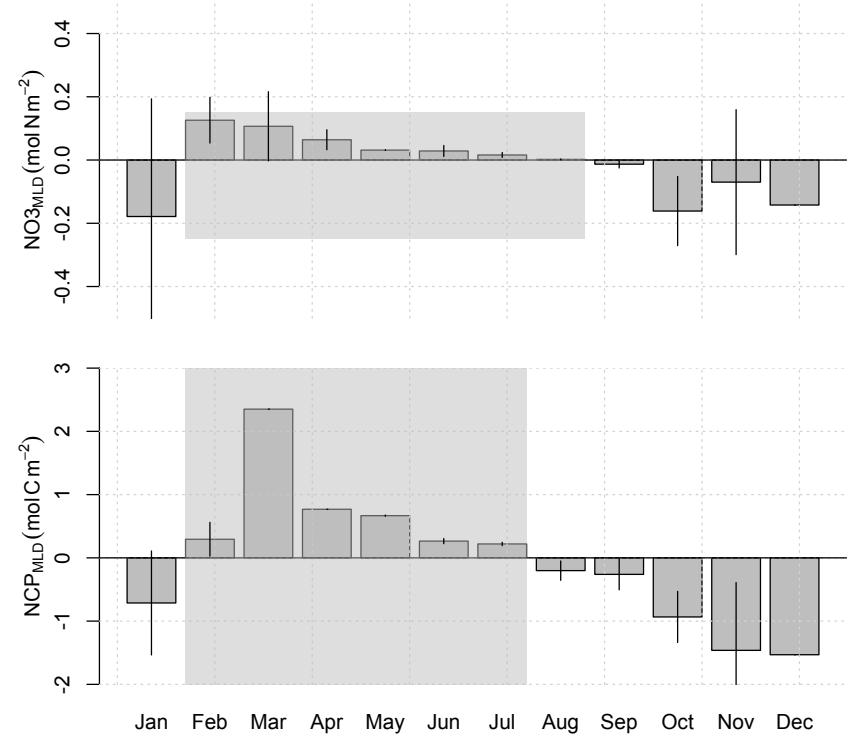

Figure 3. Monthly changes in MLD integrated $\mathrm{NO}_{3}^{-}$(top) and NCP (bottom) with \pm 1 SD (vertical bars). The shaded grey area indicates the months over which the seasonal new production $\left(0.37 \pm 0.14 \mathrm{~mol} \mathrm{~N} \mathrm{~m}^{-2}\right)$ and NCP $\left(4.57 \pm 0.85 \mathrm{~mol} \mathrm{C} \mathrm{m}^{-2}\right)$ were

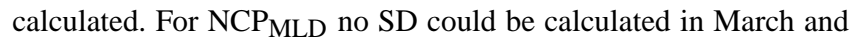
April, and SD is also lacking for December for both $\mathrm{NCP}_{\mathrm{MLD}}$ and $\mathrm{NO}_{3}$ MLD (see Sect. 2.3 for calculations).

consider the effect of air-sea exchange. The monthly MLDintegrated $\mathrm{NO}_{3}^{-}$changes $\left(\Delta \mathrm{NO}_{3}\right.$ in $\left.\mathrm{mol} \mathrm{N} \mathrm{m}{ }^{-2}\right)$ were calculated as:

$\mathrm{NO}_{3 \mathrm{MLD}}=\left(\Delta \mathrm{NO}_{3 m+1}-\Delta \mathrm{NO}_{3 m}\right) \times \frac{\left(\mathrm{MLD}_{m+1}+\mathrm{MLD}_{m}\right)}{2}$.

Summing up the months with a net drawdown in $\mathrm{NO}_{3}^{-}$ gives the seasonal new production.

Net primary production (NPP) was estimated from satellite data using the Vertically Generalised Production Model (Behrenfeld and Falkowski, 1997), which requires inputs of chlorophyll concentration, sea surface temperature and photosynthetically available radiation data, here taken from NASA's MODIS Aqua satellite (reprocessing R2012.0). The NPP data were downloaded from the Ocean Productivity website (see Table 1).

\subsection{Particle tracking and cross-correlations}

In addition to estimating the surface origin of particles sinking to the sediment trap using a simple $100 \mathrm{~km}$ box around the PAP observatory, we also used modelled velocity fields to determine the likely source region. The velocity field $(u$ and $v$ components) was taken from the NEMO model (Madec, 2008) run at NOC at 5-day, $1 / 4^{\circ}$ resolution for the period 2002-2011. The model has 75 depth levels increasing in thickness with depth, ranging from $1 \mathrm{~m}$ near surface to $200 \mathrm{~m}$ at $6000 \mathrm{~m}$ depth. All particles reaching the PAP sediment trap at $3000 \mathrm{~m}$ depth are assumed to have a sinking speed of $100 \mathrm{~m} \mathrm{day}^{-1}$, which is chosen because it falls in the middle of the range observed for particle sinking speeds at the PAP observatory of between 60 and $180 \mathrm{~m} \mathrm{day}^{-1}$ (Riley et al., 2012; Villa-Alfageme et al., 2014). Particles are tracked backwards in time in three dimensions by linear interpolation of the gridded velocity field to the local position of the particle, until they reach the surface (30 days after release).

The cross-correlation between the sediment trap data and either NPP in a $100 \mathrm{~km}$ box around the PAP observatory or in source locations identified by particle tracking, were calculated using the ccf function in $\mathrm{R}$ ( $\mathrm{R}$ Development Core Team, 2012). The cross-correlations were performed on monthly anomalies (monthly climatology - observed monthly value), to avoid possible inflation of $p$ values due to auto-correlation. To test for significant differences between the correlation coefficients the Fisher $r$ to $z$ transformation was used (twotailed test, with two dependent correlations sharing one variable), from the R library "Psych" (Fisher, 1915; Revelle, 2012).

\section{Results}

Time series data from 2003 to 2012 from the PAP surface mooring and sediment trap are shown in Fig. 1. The temperature and salinity (both PAP sensors and Argo $30 \mathrm{~m}$ ) varied in the range $12-18$ and $35.4-35.8^{\circ} \mathrm{C}$, respectively. The mixed layer depths (MLD) were fairly consistent between years, although the winter mixed layer only extended down to $\sim 100 \mathrm{~m}$ in 2010 . There was a pronounced seasonal drawdown in $p \mathrm{CO}_{2}$ (similarly for DIC), with summer values as low as $300 \mu \mathrm{atm}$ during August 2004 and typical winter values between 360-380 $\mu \mathrm{atm}$. Corresponding seasonal trends were seen for $\mathrm{NO}_{3}^{-}$, with a winter maximum of $10 \mu \mathrm{mol} \mathrm{kg}^{-1}$ in March 2004 and values close to detection limit during summer. The strongest bloom was observed in June 2011 with Chl $a$ concentrations between 3 and $5 \mu \mathrm{L} \mathrm{L}^{-1}$, with higher than typical summer values of around $2 \mu \mathrm{g} \mathrm{L}^{-1}$. The air-sea $\mathrm{CO}_{2}$ flux was negative (i.e. oceanic uptake of $\mathrm{CO}_{2}$ ) throughout the time period, with an average uptake of around $1.5 \mathrm{mmol} \mathrm{m}^{-2} \mathrm{day}^{-1}$. There were 3 years with unusually high sediment fluxes, with short bursts of high flux during summer in 2004, 2009 and 2012.

The monthly climatology (or average seasonal cycle) for temperature showed a seasonal warming of around $5^{\circ} \mathrm{C}$, with very good overlap between the temperatures measured by the PAP sensor and the Argo floats at $30 \mathrm{~m}$ (see monthly climatologies in Fig. 2). There was little seasonal variation in salinity, although the Argo float data are generally around 0.05 lower than the salinity measured by the sensors at the PAP observatory. The summer MLD was around $30 \mathrm{~m}$ (usually between May and October), and mixing extended down to $250 \mathrm{~m}$ depth in winter. The $p \mathrm{CO}_{2}$ decreased by around $30 \mu$ atm from winter values to the summer minimum in $\mathrm{Au}$ - 
gust (reduction of around $35 \mu \mathrm{mol} \mathrm{kg}{ }^{-1}$ for DIC), while $\mathrm{NO}_{3}^{-}$ decreased by around $5 \mu \mathrm{mol} \mathrm{kg}{ }^{-1}$ to the summer minimum typically found in September. There was a gradual build-up of Chl $a$ from February, with highest values typically found between May and July with large standard deviations reflecting the high interannual variability in Fig. 1. There was no clear seasonal signal in air-sea $\mathrm{CO}_{2}$ flux, with high variability throughout the year. The sediment fluxes had high interannual variability, however, the highest volume flux was typically found in June, while an autumn peak was often found for dry weight and POC in September or October.

The monthly MLD-integrated $\mathrm{NO}_{3}^{-}$changes (NO3 ${ }_{\mathrm{MLD}}$ ) were positive from February to August (Fig. 3), which means that during these months there was a net decrease in $\mathrm{NO}_{3}^{-}$concentrations in the mixed layer caused by biological drawdown. Conversely, there were negative $\mathrm{NO}_{3}$ MLD from September to February, meaning that during these months the $\mathrm{NO}_{3}^{-}$concentrations increased due to remineralization and entrainment of new nutrients through winter mixing. This corresponds to an MLD-integrated seasonal new production (from February to August, see Sect. 2.3 for calculation) of $0.37 \pm 0.14 \mathrm{~mol} \mathrm{~N} \mathrm{~m}^{-2}$. Note that all uncertainties given for production estimates in this work are due to interannual variability, as explained in Sect. 2.3. The monthly MLDintegrated changes in NCP $\left(\mathrm{NCP}_{\mathrm{MLD}}\right)$ showed the same seasonal trend, with a positive $\mathrm{NCP}_{\mathrm{MLD}}$ (i.e. decrease in DIC concentrations) from February to July. In addition, there was a much higher $\mathrm{NCP}_{\mathrm{MLD}}$ in March compared to the other spring/summer months. The MLD-integrated seasonal NCP (from February to July) was $4.57 \pm 0.85 \mathrm{~mol} \mathrm{C} \mathrm{m}^{-2}$.

Tracking of the particles arriving at the sediment trap at $3000 \mathrm{~m}$ at the PAP observatory (see Sect. 2.4), revealed that the source locations of particles could vary substantially between years, and also on an annual timescale (Fig. 4). The satellite NPP in these source regions also varied markedly, and the highest NPP of around $210 \mathrm{mmol} \mathrm{C} \mathrm{m}^{-2} \mathrm{day}^{-1}$ was found in 2009.

There was a high cross-correlation between the seasonal anomalies of NPP in source locations identified by the particle tracking and the volume flux in the sediment trap $(+0.62$; Fig. 5$)$ at lag $=0$ months. The corresponding crosscorrelation for NPP averaged over a $100 \mathrm{~km}$ box around the PAP observatory and volume flux was considerably lower (+0.48; Fig. 5), however the difference between the two cross-correlations was not significant (Fisher transformation, $n=111, z=1.58, p=0.11$ ). The correlation coefficients between either dry weight and POC and the two different NPP estimates were lower, and similarly showed no significant difference between either using the NPP identified by particle tracking or a $100 \mathrm{~km}$ box. The highest cross-correlations between NPP and dry weight was found at lag $=-1$ month (i.e. dry weight lagged NPP by 1 month), while it was at lag $=-3$ months for NPP and POC. We also tested the crosscorrelations using the NPP at the exact latitude and longitude

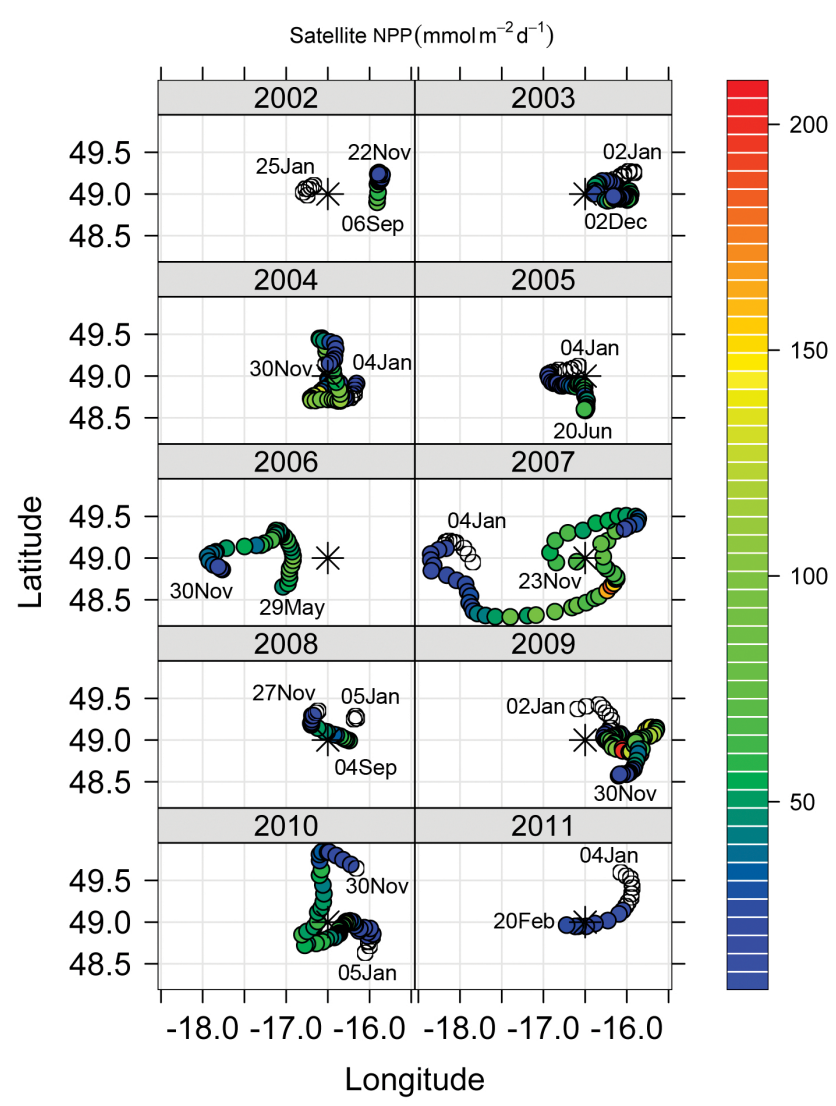

Figure 4. Satellite NPP $\left(\mathrm{mmol} \mathrm{C} \mathrm{m}{ }^{-2} \mathrm{~d}^{-1}\right)$ in the source regions for the sediment trap as identified by particle tracking. The star shows the position of the PAP mooring and unfilled circles indicate that no NPP estimate was available from satellite data (most often during January and February). The start and end dates of the data for each year are indicated in the panels.

of the PAP observatory $\left(49^{\circ} \mathrm{N}, 16^{\circ} \mathrm{W}\right)$ and extending the box to $200 \mathrm{~km}$ around the observatory, but there were no significant differences in cross-correlations using these instead of the mean of a $100 \mathrm{~km}$ box around the PAP observatory as above (results not shown).

\section{Discussion}

\subsection{Estimates of surface productivity}

The seasonal cycles of carbon $\left(p \mathrm{CO}_{2} / \mathrm{DIC}\right)$ and $\mathrm{NO}_{3}^{-}$at the PAP observatory are characteristic of highly productive subpolar regions, where cooling, convection and remineralization cause a winter maximum, while drawdown from biological production during spring and summer causes a minimum during late summer (Takahashi et al., 2002). This is true also for $p \mathrm{CO}_{2}$, because the decreasing effect of production is stronger than the opposing effect of warming. The same seasonal effects are seen in the MLD-integrated changes in $\mathrm{NO}_{3}^{-}$and DIC concentrations used to calculate new pro- 
NPP in source regions
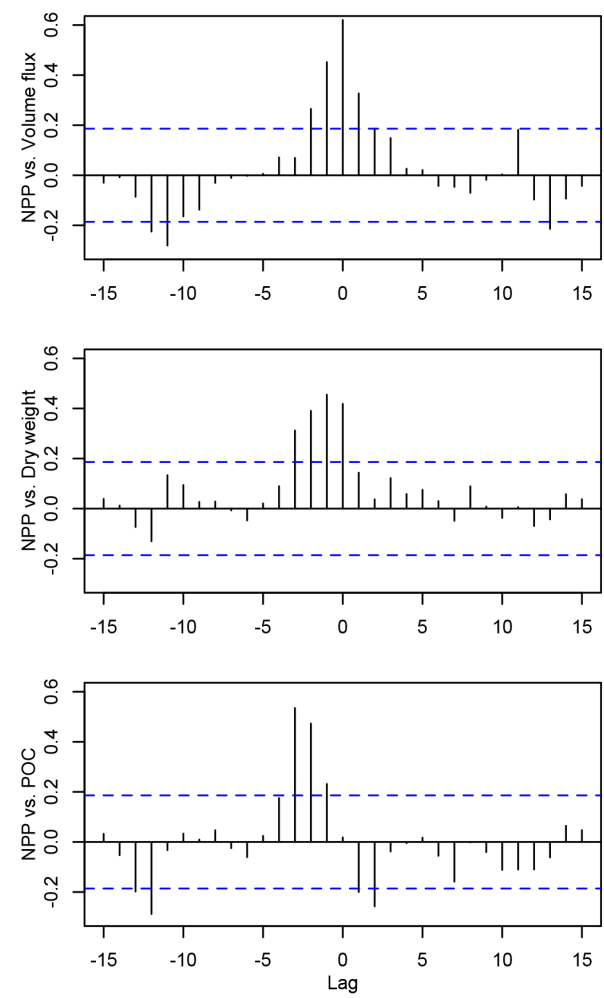

NPP in PAP 100km box
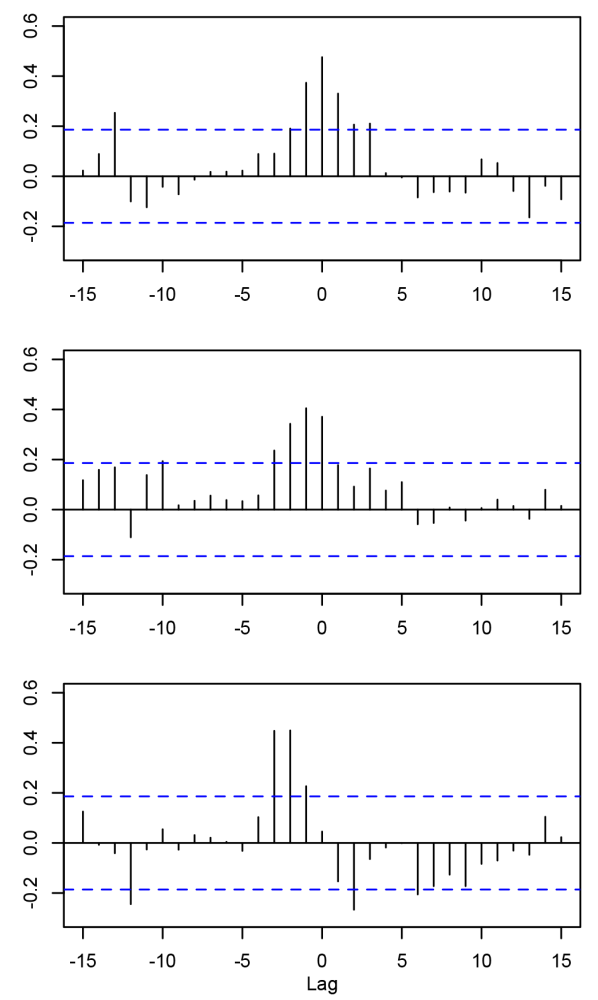

Figure 5. Cross-correlations between sediment trap data (top: volume flux, middle: dry weight, bottom: POC) and NPP in the source regions defined by particle tracking (left) or in a $100 \mathrm{~km}$ box around the PAP observatory (right). The dashed lines show the $95 \%$ confidence intervals. The unit of the lags is months.

duction and NCP (i.e. Fig. 3). There were positive monthly changes in $\mathrm{NO}_{3}$ MLD and $\mathrm{NCP}_{\mathrm{MLD}}$ during spring/summer, due to decreasing concentrations related to biological production within a shallowing or fairly stable mixed layer. During winter the combined effects of cooling, deep mixing and remineralization caused negative $\mathrm{NO}_{3}$ MLD and NCP $\mathrm{MLD}_{\mathrm{ML}}$ (i.e. increasing $\mathrm{NO}_{3}^{-}$and DIC concentrations).

The MLD-integrated seasonal NCP (from February to July) was $4.57 \pm 0.85 \mathrm{~mol} \mathrm{C} \mathrm{m}^{-2}$, which is comparable to, but lower than, the NCP calculated for the PAP observatory by Körtzinger et al. (2008) for 2004 of $6.4 \pm 1.1 \mathrm{~mol} \mathrm{C} \mathrm{m}^{-2}$ from March to early August. This is natural given that Körtzinger et al. (2008) integrated over a much deeper fixed mixed layer $(238 \mathrm{~m})$ from March until mid May, while here we used the mean MLD between consecutive months. As can be seen in Fig. 2, the MLD shallows rapidly from around $250 \mathrm{~m}$ in March to $50 \mathrm{~m}$ in May, and we believe using the actual depth of the mixed layer gives a more realistic estimate of NCP during this period of rapid stratification. From May to August the MLD is slightly shallower than the depth of the sensors at $30 \mathrm{~m}$, which could influence our estimates of NCP and new production. This uncertainty is impossible to quantify without measurements from within the mixed layer, although the effect is believed to be minor. It could poten- tially overestimate biological production due to more readily available nutrients at $30 \mathrm{~m}$ than within the mixed layer, or lead to an underestimate due to additional drawdown within the mixed layer. Consistent with Körtzinger et al. (2008), we find that the strongest NCP occurs before the onset of shallow stratification in summer, with an NCP maximum in March. The MLD-integrated seasonal new production (from February to August) was $0.37 \pm 0.14 \mathrm{~mol} \mathrm{~N} \mathrm{~m}^{-2}$. This is within the range of new production estimates, using different approaches, from $0.23-1.1 \mathrm{~mol} \mathrm{~N} \mathrm{~m}^{-2}$ from the Northeast Atlantic Ocean and Icelandic Sea (Fernández I et al., 2005; Hartman et al., 2010; Jeansson et al., 2015).

Converting the new production in terms of nitrogen to carbon units using the Redfield ratio of 6.6 (Redfield, 1958), gives a value of $2.5 \mathrm{~mol} \mathrm{C} \mathrm{m}^{-2}$, which is substantially smaller than the NCP calculated from DIC changes. However, there is not necessarily any basis for assuming that new production and NCP should be equal, even in a steady-state system (cf. Laws, 1991). This would imply that carbon is assimilated and recycled by heterotrophs (as respiration is included in NCP) in the same ratio as nitrogen is assimilated by autotrophs during new production, which need not be the case (i.e. variable stoichiometry, see review by Sterner and Elser, 2002). The fact that the production calculated from carbon is higher 
than the production calculated from nitrogen, is referred to as carbon overconsumption (Toggweiler, 1993), and has been demonstrated repeatedly in the North Atlantic (Sambrotto et al., 1993; Körtzinger et al., 2001; Koeve, 2006). It has also been shown specifically for the PAP observatory (Körtzinger et al., 2008; Painter et al., 2010). The seasonal C : N ratio for the PAP observatory from this study (i.e. NCP/new production) would be $\approx 12$, which is greatly exceeding the Redfield ratio, although within the range of $\mathrm{C}: \mathrm{N}$ ratios previously found in this region (Koeve, 2006; Körtzinger et al., 2008; Painter et al., 2010).

Studies have found $\mathrm{N}_{2}$ fixation to be low or zero at latitudes $>40^{\circ} \mathrm{N}$ (PAP observatory is at $49^{\circ} \mathrm{N}$ ) in the North Atlantic (Moore et al., 2009; Reynolds et al., 2007), therefore $\mathrm{N}_{2}$ fixation is not thought to be an important factor for $\mathrm{C}$ overconsumption. Therefore, the $\mathrm{C}$ overconsumption must be sustained by preferential remineralization of nutrients, either in slowly sinking detritus (Sambrotto et al., 1993; Thomas et al., 1999; Körtzinger et al., 2001) or a build up of C-rich (and N-poor) DOM in the euphotic zone (Williams, 1995; Kähler and Koeve, 2001; Falck and Anderson, 2005). Additionally transparent exopolymer particles (TEP; Alldredge et al., 1993), which have been shown to have high $\mathrm{C}: \mathrm{N}$ ratios (Engel and Passow, 2001) could represent a route for the $\mathrm{C}$ overconsumed in the euphotic zone to reach the deep ocean (Koeve, 2005). The regenerated nutrients can fuel additional production in the euphotic zone, and consequently estimates of new production based on nitrate might underestimate production rates (Thomas et al., 1999).

The degree to which the $\mathrm{C}$ overconsumed in the surface waters reaches the deep ocean, and thus is sequestered on long timescales is important, because it represents a potential negative feedback on atmospheric $\mathrm{CO}_{2}$. Studies have shown an increasing $\mathrm{C}: \mathrm{N}$ of sinking material due to preferential remineralization of nutrients (Schneider et al., 2003; Lee and Cronin, 1984), and the potential feedback of a depth-dependent $\mathrm{C}: \mathrm{N}$ ratio may influence atmospheric $\mathrm{CO}_{2}$ concentrations by about $20 \mathrm{ppm}$ (Schneider et al., 2004). However, the deep ocean remineralization ratio of $\mathrm{C}: \mathrm{N}$ has been shown to be close to the Redfield ratio (Anderson and Sarmiento, 1994), and if the C overconsumption is mainly during summer (Koeve, 2004; Jiang et al., 2013) and remineralized above the depth of the winter mixed layer, it could be questioned whether the "extra-Redfield" $\mathrm{C}$ is sequestered in the deeper ocean, and can therefore influence the oceanic C-budget on longer timescales (Koeve, 2006). However, the deep ocean remineralization rates of Anderson and Sarmiento (1994) did not include the Atlantic Ocean. A study on the remineralization ratios in the North Atlantic Ocean specifically showed higher than Redfield C : nutrient ratios in the remineralized material in the deeper waters, and thereby a higher $\mathrm{C}$ drawdown by the biological carbon pump than would be expected from applying Redfield ratios in the formation of organic matter (Thomas, 2002).
The export flux of POC around the PAP observatory has been quantified in several studies using different techniques (see overview in Fig. 4 in Riley et al. (2012). The average POC flux in the upper $170 \mathrm{~m}$ obtained from PELAGRA drifting sediment trap deployments for short periods of time (3-5 days) between 2003 and 2005 was $72 \mathrm{mg} \mathrm{C} \mathrm{m}^{-2} \mathrm{~d}^{-1}$ (Lampitt et al., 2008b). During a cruise in August 2009 the flux was found to be 84 and $146 \mathrm{mg} \mathrm{C} \mathrm{m}^{-2} \mathrm{~d}^{-1}$ at $50 \mathrm{~m}$, using PELAGRA and a marine snow catcher, respectively ( $\mathrm{Ri}-$ ley et al., 2012). Using the ${ }^{234} \mathrm{Th}$ technique the flux of POC at $100 \mathrm{~m}$ in the vicinity of the PAP observatory was determined to be in the range between 64 and $207 \mathrm{mg} \mathrm{C} \mathrm{m}^{-2} \mathrm{~d}^{-}$ (based on measurements from a single cruise and long-time trap data; Lampitt et al., 2008b; Thomalla et al., 2008). The export ratio describes the efficiency of nutrient utilization in the euphotic zone, and is often calculated as the POC flux at the base of the euphotic zone or a fixed depth (typically $100 \mathrm{~m}$ ), divided by the NPP Dugdale and Goering (1967). Using an average of the above values for POC flux out of the surface layer of $115 \pm 61 \mathrm{mg} \mathrm{C} \mathrm{m}^{-2} \mathrm{~d}^{-1}$ and the March-July average NPP in the $100 \mathrm{~km}$ box around the PAP observatory of $772 \mathrm{mg} \mathrm{C} \mathrm{m}^{-2} \mathrm{~d}^{-1}$ gives an export ratio of 0.15 . This is identical to the estimate by Lampitt et al. (2008b) for the PAP observatory during post-bloom conditions from 2003-2005, and consistent with the estimate by Henson et al. (2011) of between 10 and $30 \%$ for temperate and sub-polar waters, respectively.

\subsection{Links between surface production and deep ocean flux of POC}

Using particle tracking to identify the source location of material arriving in the sediment trap at $3000 \mathrm{~m}$ at the PAP observatory showed that the particles could originate up to $140 \mathrm{~km}$ away (in 2007; Fig. 4). There was large variation in the source location of particles between years, depending on the prevailing current conditions in the given year. There was also large variation within individual years, but the satellite NPP generally increased during spring and decreased during autumn along the trajectory of the particles reflecting the seasonal cycle. Mesoscale variability will also contribute to the variability in source location of particles, both between and within years. The highest NPP was found in 2009 (around $210 \mathrm{mmol} \mathrm{C} \mathrm{m}^{-2} \mathrm{day}^{-1}$ ), which corresponds to very high fluxes in both volume flux and dry weight in the sediment trap at the PAP observatory (Fig. 1). Interestingly, there was not a strong bloom at the PAP observatory according to the in situ Chl $a$ observations at $30 \mathrm{~m}$ depth (sensor data available from May to late July; Fig. 1), while the satellite NPP showed high correlations with the volume flux and dry weight in the sediment trap. The correlations were highest between the NPP in source locations as identified by particle tracking, compared to the mean NPP in a fixed $100 \mathrm{~km}$ box around the PAP observatory. However, the differences in correlation coefficients were not statistically different, and more 
observations ( $n=111$ in present analysis) would be needed to determine if using a particle tracking approach when examining the origin of particles in sediment traps indeed gives higher correlations.

The transfer efficiency is a useful metric to describe the long-term removal of carbon (> 100 years) from the atmosphere (cf. De La Rocha and Passow, 2012). Using the same average POC flux of the surface layer $(0-170 \mathrm{~m})$ as in the calculation of the export flux above and the average flux between March and July of POC at $3000 \mathrm{~m}$ from the sediment trap at the PAP observatory $\left(5.1 \mathrm{mg} \mathrm{C} \mathrm{m}^{-2} \mathrm{~d}^{-1}\right)$, the transfer efficiency was calculated to be $4 \%$. This corresponds well with the transfer efficiency between 5 and $10 \%$ found for the $50^{\circ} \mathrm{N}$ region by Henson et al. (2012b), indicative of regions where the available nitrate is not fully consumed and with strong seasonal mixing. The fairly high export ratio $(15 \%)$ and low transfer efficiency (4\%) fits the description of the general trends in high-latitude ecosystems in the above-cited study well. This dichotomy in efficiencies implies that although a large proportion of the primary production is exported below the euphotic zone, this material is relatively labile and is efficiently remineralized in the mesopelagic zone, so that only a very small fraction of the exported organic matter reaches the deep ocean and is stored on long timescales.

The PAP observatory currently sits near the boundary between the sub-polar and sub-tropical gyres of the North Atlantic. Seasonably variable areas, like the sub-polar region, are thought to export a higher fraction of labile material than sub-tropical regions (Lutz et al., 2007). As climate change is predicted to result in the oligotrophic gyres expanding over the next century (Sarmiento et al., 2004), the PAP observatory will likely transition into more sub-tropical conditions. This could result in more refractory material being exported at the PAP observatory, potentially reversing the pattern we report here with a high export ratio and low transfer efficiency. In addition, a more strongly positive NAO index is predicted due to climate change (Gillett, 2003), which is expected to increase diatom abundance at the PAP observatory, and result in reduced organic carbon flux to the deep ocean (Henson et al., 2012a). Although the precise response of the biological carbon pump to climate change is as yet unclear, transition-zone regions between gyres (such as the PAP observatory), could be among the systems that are most strongly affected by climate change (Henson et al., 2013).

\section{Conclusions}

The PAP observatory is characterized by strong interannual variability in hydrography, biogeochemistry, and especially sediment fluxes. The seasonal cycles of carbon and nitrogen show a winter maximum and summer minimum, characteristic of highly productive sub-polar regions. The MLD-integrated seasonal NCP (from February to July) was $4.57 \pm 0.85 \mathrm{~mol} \mathrm{C} \mathrm{m}^{-2}$, which is consistent with, but slightly lower than the estimate by Körtzinger et al. (2008) for 2004. The MLD-integrated seasonal new production (from February to August) was $0.37 \pm 0.14 \mathrm{~mol} \mathrm{~N} \mathrm{~m}^{-2}$, which gives a Redfield ratio (NCP/new production) of 12 , corroborating other reports of carbon overconsumption for the North Atlantic (Sambrotto et al., 1993; Körtzinger et al., 2001; Koeve, 2006) and the PAP observatory specifically (Körtzinger et al., 2008; Painter et al., 2010).

The export ratio was $15 \%$, while the transfer efficiency was $4 \%$, which is typical of high-latitude ecosystems where, although a large proportion of the primary production is exported out of the euphotic zone, this material is relatively labile and therefore remineralized before it reaches the deep ocean. It is hypothesized that the export regime at the PAP observatory could change with climate change, as the region will probably transition into more sub-tropical conditions over the next century (Sarmiento et al., 2004; Lutz et al., 2007).

Using particle tracking to identify the source regions of material reaching the sediment trap at the PAP observatory, revealed higher correlations between NPP in the identified source regions and export flux than other methods. However, more observations are needed to establish if a particletracking approach indeed gives added value in sediment trap analyses.

Acknowledgements. We would like to acknowledge the various ship crew, engineers and scientists involved in preparation, deployment and recovery of the PAP sustained observatory moorings, especially Jon Campbell and Mark Hartman. We wish to thank Maureen Pagnani, Athanos Gkritzalis-Papadopoulos, Zong-Pei Jiang and Andres Cianca for compilation, quality control and calibration of PAP data. Mooring data and support for this research was provided by the European research projects ANIMATE (Atlantic Network of Interdisciplinary Moorings and Time Series for Europe), MERSEA (Marine Environment and Security for the European Sea), EUR OCEANS (European Network of Excellence for Ocean Ecosystems Analysis) and EuroSITES grant agreement EU 202955. The work was also supported through the Natural Environment Research Council (NERC), UK, project Oceans 2025 and National Capability. H. F. was supported by EU FP7, through projects MEECE (212085), EURO-BASIN (264933) and GreenSeas (265294).

Edited by: C. Robinson

\section{References}

Alldredge, A. L., Passow, U., and Logan, B. E.: The Abundance and Significance of a Class of Large, Transparent Organic Particles in the Ocean, Deep-Sea Res. Pt. I, 40, 1131-1140, 1993.

Anderson, L. A. and Sarmiento, J. L.: Redfield Ratios of Remineralization Determined by Nutrient Data-Analysis, Global Biogeochem. Cy., 8, 65-80, 1994. 
Behrenfeld, M. J. and Falkowski, P. G.: Photosynthetic rates derived from satellite-based chlorophyll concentration, Limnol. Oceanogr., 42, 1-20, 1997.

Berelson, W. M.: The flux of partuculate organic carbon into the ocean interior: A comparison of four U.S. JGOFS regional studies, Oceanography, 14, 59-67, 2001.

De La Rocha, C. L. and Passow, U. (Eds): The biological pump, Vol. 6, Elsevier, Oxford, 2012.

Dickson, A. G.: Standard Potential of the Reaction - $\mathrm{AgCl}(\mathrm{s})+1 / 2$ $\mathrm{H}_{2}(\mathrm{~g})=\mathrm{Ag}(\mathrm{s})+\mathrm{HCl}(\mathrm{aq})$ and the Standard Acidity Constant of the Ion Hso4- in Synthetic Sea-Water from 273.15 K to 318.15 K, J. Chem. Thermodyn., 22, 113-127, 1990.

Dickson, A. G. and Riley, J. P.: The effect of analytical error on the evaluation of the components of the aquatic carbon-dioxide system, Mar. Chem., 6, 77-85, 1978.

Dickson, A. G., Sabine, C. L., and Chrsitian, J. R.: Guide to best practices for ocean $\mathrm{CO}_{2}$ measurements, PICES Special Publication, Sidney, British Columbia, North Pacific Marine Science Organization, Book 3, 2007.

Dugdale, R. C. and Goering, J. J.: Uptake of New and Regenerated Forms of Nitrogen in Primary Productivity, Limnol. Oceanogr., 12, 196-206, doi:10.4319/lo.1967.12.2.0196, 1967.

Engel, A. and Passow, U.: Carbon and nitrogen content of transparent exopolymer particles (TEP: in relation to their Alcian Blue adsorption, Mar. Ecol.-Prog. Ser., 219, 1-10, 2001.

Eppley, R. W. and Peterson, B. J.: Particulate Organic-Matter Flux and Planktonic New Production in the Deep Ocean, Nature, 282, 677-680, 1979.

Falck, E. and Anderson, L. G.: The dynamics of the carbon cycle in the surface water of the Norwegian Sea, Mar. Chem., 94, 43-53, 2005.

Falkowski, P. G., Barber, R. T., and Smetacek, V.: Biogeochemical controls and feedbacks on ocean primary production, Science, 281, 200-206, 1998.

Fernández, I. C., Raimbault, P., Garcia, N., Rimmelin, P., and Caniaux, G.: An estimation of annual new production and carbon fluxes in the northeast Atlantic Ocean during 2001, J. Geophys. Res.-Oceans, 110, C07S13, doi:10.1029/2004JC002616, 2005.

Fisher, R. A.: Frequency distribution of the values of the correlation coefficient in samples of an indefinitely large population, Biometrika, 10, 507-521, 1915.

Francois, R., Honjo, S., Krishfield, R., and Manganini, S.: Factors controlling the flux of organic carbon to the bathypelagic zone of the ocean, Global Biogeochem. Cy., 16, 34-1-34-20, doi:10.1029/2001GB001722, 2002.

Gaarder, T. and Gran, H. H.: Investigation of the production of phytoplankton in the Oslo Fjord, Rapp. P.V. Cons. Int. Explor. Mer., $42,1-48,1927$.

Gaillard, F., Autret, E., Thierry, V., Galaup, P., Coatanoan, C., and Loubrieu, T.: Quality Control of Large Argo Datasets, J. Atmos. Ocean. Tech., 26, 337-351, 2009.

Gillett, N., Graf, H., and Osborn, T.: Climate Change and the North Atlantic Oscillation. The North Atlantic Oscillation: Climatic Significance and Environmental Impact, edited by: Hurrell, J. W., Geophys. Mono., 134, 231-244, 2003.

GLOBALVIEW-CO2: Cooperative Atmospheric Data Integration Project - Carbon Dioxide, NOAA ESRL, Boulder, Colorado, available at: http://www.esrl.noaa.gov/gmd/ccgg/ globalview/co2/co2_download.html (last access: June 2013), 2012.

Gruber, N.: The marine nitrogen cycle: Overview and challenges, in: Nitrogen in the Marine Environment, edited by: Capone, D. G., Bronk, D. A., Mulholland, M. R., and Carpenter, E. J., Book 2, Elsevier, Amsterdam, 2008.

Hartman, S. E., Larkin, K. E., Lampitt, R. S., Lankhorst, M., and Hydes, D. J.: Seasonal and inter-annual biogeochemical variations in the Porcupine Abyssal Plain 2003-2005 associated with winter mixing and surface circulation, Deep-Sea Res. Pt. II, 57, 1303-1312, 2010.

Hartman, S. E., Lampitt, R. S., Larkin, K. E., Pagnani, M., Campbell, J., Gkritzalis, T., Jiang, Z. P., Pebody, C. A., Ruhl, H. A., Gooday, A. J., Bett, B. J., Billett, D. S. M., Provost, P., McLachlan, R., Turton, J. D., and Lankester, S.: The Porcupine Abyssal Plain fixed-point sustained observatory (PAP-SO): variations and trends from the Northeast Atlantic fixed-point time-series, Ices J. Mar. Sci., 69, 776-783, 2012.

Henson, S., Cole, H., Beaulieu, C., and Yool, A.: The impact of global warming on seasonality of ocean primary production, Biogeosciences, 10, 4357-4369, doi:10.5194/bg-10-4357-2013, 2013.

Henson, S. A., Dunne, J. P., and Sarmiento, J. L.: Decadal variability in North Atlantic phytoplankton blooms, J. Geophys. Res.Oceans., 114, C04013, doi:10.1029/2008JC005139, 2009.

Henson, S. A., Sanders, R., Madsen, E., Morris, P. J., Le Moigne, F., and Quartly, G. D.: A reduced estimate of the strength of the ocean's biological carbon pump, Geophys. Res. Lett., 38, L04606, doi:10.1029/2011GL046735, 2011.

Henson, S. A., Lampitt, R., and Johns, D.: Variability in phytoplankton community structure in response to the North Atlantic Oscillation and implications for organic carbon flux, Limnol. Oceanogr., 57, 1591-1601, 2012a.

Henson, S. A., Sanders, R., and Madsen, E.: Global patterns in efficiency of particulate organic carbon export and transfer to the deep ocean, Global Biogeochem. Cy., 26, GB1028, doi:10.1029/2011GB004099, 2012b.

Holte, J. and Talley, L.: A New Algorithm for Finding Mixed Layer Depths with Applications to Argo Data and Subantarctic Mode Water Formation, J. Atmos. Ocean. Tech., 26, 1920-1939, 2009.

Jeansson, E., Bellerby, R. G. J., Skjelvan, I., Frigstad, H., Ólafsdóttir, S. R., and Olafsson, J.: Fluxes of carbon and nutrients to the Iceland Sea surface layer and inferred primary productivity and stoichiometry, Biogeosciences, 12, 875-885, doi:10.5194/bg-12875-2015, 2015.

Jiang, Z.-P., Hydes, D. J., Tyrrell, T., Hartman, S. E., Hartman, M. C., Dumousseaud, C., Padin, X. A., Skjelvan, I., and GonzálezPola, C.: Key controls on the seasonal and interannual variations of the carbonate system and air-sea $\mathrm{CO}_{2}$ flux in the Northeast Atlantic (Bay of Biscay), J. Geophys. Res.-Oceans, 118, 785800, 2013.

Kähler, P. and Koeve, W.: Marine dissolved organic matter: can its $\mathrm{C}: \mathrm{N}$ ratio explain carbon overconsumption?, Deep-Sea Res. Pt. I, 48, 49-62, 2001.

Koeve, W.: Spring bloom carbon to nitrogen ratio of net community production in the temperate N. Atlantic, Deep-Sea Res. Pt. I, 51, 1579-1600, 2004. 
Koeve, W.: Magnitude of excess carbon sequestration into the deep ocean and the possible role of TEP, Mar. Ecol.-Prog. Ser., 291, 53-64, 2005.

Koeve, W.: C:N stoichiometry of the biological pump in the North Atlantic: Constraints from climatological data, Global Biogeochem. Cy., 20, GB3018, doi:10.1029/2004GB002407, 2006.

Körtzinger, A., Koeve, W., Kähler, P., and Mintrop, L.: C : N ratios in the mixed layer during the productive season in the northeast Atlantic Ocean, Deep-Sea Res. Pt. I, 48, 661-688, 2001.

Körtzinger, A., Send, U., Lampitt, R. S., Hartman, S., Wallace, D. W. R., Karstensen, J., Villagarcia, M. G., Llinas, O., and DeGrandpre, M. D.: The seasonal $p \mathrm{CO}_{2}$ cycle at 49 degrees N/16.5 degrees $\mathrm{W}$ in the northeastern Atlantic Ocean and what it tells us about biological productivity, J. Geophys. Res.-Oceans, 113, C04020, doi:10.1029/2007JC004347, 2008.

Lampitt, R. S., Achterberg, E. P., Anderson, T. R., Hughes, J. A., Iglesias-Rodriguez, M. D., Kelly-Gerreyn, B. A., Lucas, M., Popova, E. E., Sanders, R., Shepherd, J. G., Smythe-Wright, D., and Yool, A.: Ocean fertilization: a potential means of geoengineering?, Philos. T. Roy. Soc. A, 366, 3919-3945, 2008a.

Lampitt, R. S., Salter, I., de Cuevas, B. A., Hartman, S., Larkin, K. E., and Pebody, C. A.: Long-term variability of downward particle flux in the deep northeast Atlantic: Causes and trends, Deep-Sea Res. Pt. II, 57, 1346-1361, 2010.

Lavigne, H. and Gattuso, J.-P.: Seacarb: seawater carbonate chemistry with $\mathrm{R}, \mathrm{R}$ package version 2.4 , available at: http://CRAN. R-project.org/package=seacarb (last access: June 2013), 2011.

Laws, E. A.: Photosynthetic Quotients, New Production and Net Community Production in the Open Ocean, Deep-Sea Res., 38, 143-167, 1991.

Laws, E. A., Falkowski, P. G., Smith, W. O., Ducklow, H., and McCarthy, J. J.: Temperature effects on export production in the open ocean, Global Biogeochem. Cy., 14, 1231-1246, 2000.

Lee, C. and Cronin, C.: Particulate amino acids in the sea: effects of primary productivity and biological decomposition, J. Mar. Res., 42, 1075-1097, 1984.

Lee, K.: Global net community production estimated from the annual cycle of surface water total dissolved inorganic carbon, Limnol. Oceanogr., 46, 1287-1297, 2001.

Lee, K., Tong, L. T., Millero, F. J., Sabine, C. L., Dickson, A. G., Goyet, C., Park, G.-H., Wanninkhof, R., Feely, R. A., and Key, R. M.: Global relationships of total alkalinity with salinity and temperature in surface waters of the world's oceans, Geophys. Res. Lett., 33, L19605, doi:10.1029/2006GL027207, 2006.

Long, M. C., Dunbar, R. B., Tortell, P. D., Smith, W. O., Mucciarone, D. A., and DiTullio, G. R.: Vertical structure, seasonal drawdown, and net community production in the Ross Sea, Antarctica, J. Geophys. Res.-Oceans, 116, C10029, doi:10.1029/2009JC005954, 2011.

Lueker, T. J., Dickson, A. G., and Keeling, C. D.: Ocean $p \mathrm{CO}_{2}$ calculated from dissolved inorganic carbon, alkalinity, and equations for $\mathrm{K}-1$ and $\mathrm{K}-2$ : validation based on laboratory measurements of $\mathrm{CO}_{2}$ in gas and seawater at equilibrium, Mar. Chem., 70, 105-119, 2000.

Lutz, M. J., Caldeira, K., Dunbar, R. B., and Behrenfeld, M. J.: Seasonal rhythms of net primary production and particulate organic carbon flux to depth describe the efficiency of biologi- cal pump in the global ocean, J. Geophys. Res.-Oceans, 112, C10011, doi:10.1029/2006JC003706, 2007.

Madec, G.: NEMO ocean engine, Note du Pole de modélisation, Institut Pierre-Simon Laplace (IPSL), France, No. 27, ISSN No 1288-1619, 2008.

Martin, J. H., Knauer, G. A., Karl, D. M., and Broenkow, W. W. Vertex - Carbon Cycling in the Northeast Pacific, Deep-Sea Res. 34, 267-285, 1987.

Moore, C., Mills, M., Matthew, M., Achterberg, E. P., Geider, R. J., LaRoche, J., Lucas, M. I., McDonagh, E. L., Pan, X., Poulton, A. J., Rijkenberg, M. J. A., Suggett, D. J., Ussher, S. J., Woodward, E., and Malcolm, S.: Large-scale distribution of Atlantic nitrogen fixation controlled by iron availability, Nat. Geosci., 2, 867-871, 2009.

Nevison, C. D., Keeling, R. F., Kahru, M., Manizza, M., Mitchell, B. G., and Cassar, N.: Estimating net community production in the Southern Ocean based on atmospheric potential oxygen and satellite ocean color data, Global Biogeochem. Cy., 26, GB1020, doi:10.1029/2011gb004040, 2012.

Nightingale, P. D., Malin, G., Law, C. S., Watson, A. J., Liss, P. S., Liddicoat, M. I., Boutin, J., and Upstill-Goddard, R. C.: In situ evaluation of air-sea gas exchange parameterizations using novel conservative and volatile tracers, Global Biogeochem. Cy., 14, 373-387, 2000.

Painter, S. C., Lucas, M. I., Stinchcombe, M. C., Bibby, T. S., and Poulton, A. J.: Summertime trends in pelagic biogeochemistry at the Porcupine Abyssal Plain study site in the northeast Atlantic, Deep-Sea Res. Pt. II, 57, 1313-1323, 2010.

Passow, U. and Carlson, C. A.: The biological pump in a high $\mathrm{CO}_{2}$ world, Mar. Ecol.-Prog. Ser., 470, 249-271, 2012.

Perez, F. F. and Fraga, F.: Association Constant of Fluoride and Hydrogen-Ions in Seawater, Mar. Chem., 21, 161-168, 1987.

Platt, T., Harrison, W. G., Lewis, M. R., Li, W. K. W., Sathyendranath, S., Smith, R. E., and Vezina, A. F.: Biological Production of the Oceans - the Case for a Consensus, Mar. Ecol.-Prog. Ser., 52, 77-88, 1989.

Quay, P. D., Peacock, C., Bjorkman, K., and Karl, D. M.: Measuring primary production rates in the ocean: Enigmatic results between incubation and non-incubation methods at Station ALOHA, Global Biogeochem. Cy., 24, GB3014, doi:10.1029/2009GB003665, 2010.

R Development Core Team: R: A language and environment for statistical computing, R Foundation for Statistical Computing, Vienna, Austria, 2012.

Redfield, A. C.: The Biological Control of Chemical Factors in the Environment, Am. Sci., 46, 205-221, 1958.

Revelle, W.: Psych: Procedures for Personality and Psychological Research Northwestern University, Evanston, available at: https: //cran.r-project.org/web/packages/psych/index.html (last access: June 2013), 2012.

Reynolds, S. E., Mather, R. L., Wolff, G. A., Williams, R. G., Landolfi, A., Sanders, R., and Woodward, E. M. S.: How widespread and important is $\mathrm{N}_{2}$ fixation in the North Atlantic Ocean?, Global Biogeochem. Cy., 21, 1-14, doi:10.1029/2006GB002886, 2007.

Riley, J. S., Sanders, R., Marsay, C., Le Moigne, F. A. C., Achterberg, E. P., and Poulton, A. J.: The relative contribution of fast and slow sinking particles to ocean carbon export, Global Biogeochem. Cy., 26, GB1026, doi:10.1029/2011GB004085, 2012. 
Sambrotto, R. N., Savidge, G., Robinson, C., Boyd, P., Takahashi, T., Karl, D. M., Langdon, C., Chipman, D., Marra, J., and Codispoti, L.: Elevated Consumption of Carbon Relative to Nitrogen in the Surface Ocean, Nature, 363, 248-250, 1993.

Sarmiento, J. L., Slater, R., Barber, R., Bopp, L., Doney, S. C., Hirst, A. C., Kleypas, J., Matear, R., Mikolajewicz, U., Monfray, P., Soldatov, V., Spall, S. A., and Stouffer, R.: Response of ocean ecosystems to climate warming, Global Biogeochem. Cy., 18, GB3003, doi:10.1029/2003GB002134, 2004.

Sarmiento, J. L. and Gruber, N.: Ocean Biogeochemical Dyamics, Princeton University Press, Princeton, New Jersey, USA, 526 pp., 2006.

Schneider, B., Schlitzer, R., Fischer, G., and Nothig, E. M.: Depthdependent elemental compositions of particulate organic matter (POM) in the ocean, Global Biogeochem. Cy., 17, GB1032, doi:10.29/2002GB001871, 2003.

Schneider, B., Engel, A., and Schlitzer, R.: Effects of depthand $\mathrm{CO}_{2}$-dependent $\mathrm{C}: \mathrm{N}$ ratios of particulate organic matter (POM: on the marine carbon cycle, Global Biogeochem. Cy., 18, GB2015, doi:10.1029/2003GB002184, 2004.

Steinberg, D. K., Cope, J. S., Wilson, S. E., and Kobari, T.: A comparison of mesopelagic mesozooplankton community structure in the subtropical and subarctic North Pacific Ocean, Deep-Sea Res. Pt. II, 55, 1615-1635, 2008.

Sterner, R. W. and Elser, J. J.: Ecological Stoichiometry: the biology of elements from molecules to the biosphere, Princeton University Press, Princeton, New Jersey, 464 pp., 2002.

Takahashi, T., Sutherland, S. C., Sweeney, C., Poisson, A., Metzl, N., Tilbrook, B., Bates, N., Wanninkhof, R., Feely, R. A., Sabine, C., Olafsson, J., and Nojiri, Y.: Global sea-air $\mathrm{CO}_{2}$ flux based on climatological surface ocean $p \mathrm{CO}_{2}$, and seasonal biological and temperature effects, Deep-Sea Res. Pt. II, 49, 1601-1622, 2002.

Thomas, H.: Remineralization ratios of carbon, nutrients, and oxygen in the North Atlantic Ocean: A field databased assessment, Global Biogeochem. Cy., 16, GB1051, doi:10.1029/2001GB001452, 2002.
Thomas, H., Ittekkot, V., Osterroht, C., and Schneider, B.: Preferential recycling of nutrients - the ocean's way to increase new production and to pass nutrient limitation?, Limnol. Oceanogr., 44, 1999-2004, 1999.

Thomalla, S. J., Poulton, A. J., Sanders, R., Turnewitsch, R., Holligan, P. M., and Lucas, M. I.: Variable export fluxes and efficiencies for calcite, opal, and organic carbon in the Atlantic Ocean: A ballast effect in action?, Global Biogeochem. Cy., 22, GB1010, doi:10.1029/2007GB002982, 2008.

Toggweiler, J. R.: Oceanography - Carbon Overconsumption, Nature, 363, 210-211, 1993.

Villa-Alfageme, M., De Soto Borrero, F., Le Moigne, F., Giering, S. L., and Sanders, R.: Observations and modeling of slow sinking particles in the Twilight Zone, Global Biogeochem. Cy., 28, 1327-1342, 2014.

Wanninkhof, R.: Relationship between Wind-Speed and GasExchange over the Ocean, J. Geophys. Res.-Oceans, 97, 73737382, 1992.

Wanninkhof, R., Bakker, D., Bates, N., Olsen, A., Steinhoff, T., and Sutton, A.,: Incorporation of Alternative Sensors in the SOCAT Database and Adjustments to Dataset Quality Control Flags. Carbon Dioxide Information Analysis Center, Oak Ridge National Laboratory, US Department of Energy, Oak Ridge, Tennessee, 2013.

Weiss, R. F.: Carbon dioxide in water and seawater: The solubility of a non-ideal gas, Mar. Chem. 2, 203-215, 1974.

Williams, P. J. L.: Evidence for the Seasonal Accumulation of Carbon-Rich Dissolved Organic Material, Its Scale in Comparison with Changes in Particulate Material and the Consequential Effect on Net C/N Assimilation Ratios, Mar. Chem., 51, 17-29, 1995. 